\title{
Rekomendasi Pemilihan Produk Tabungan Bank Menggunakan Metode Weighted Product (WP)
}

\author{
Jevi Ariyanti", Agus Sidiq Purnomo** \\ *,** Program Studi Teknik Informatika, Fakultas Teknologi Informasi, Universitas Mercu Buana \\ Yogyakarta \\ *jeviariyanti1801@gmail.com, ${ }^{* *}$ sidiq@mercubuana-yogya.ac.id
}

\begin{abstract}
ABSTRAK
Many banks in Indonesia, both public and private banks, offer different advantages to the customers. As a result, it is often difficult for the public to decide where to save their money. For this reason, the writer propose a decision support system to help recommend a bank as a smart solution for saving.

This study employed the Weighted Product (WP) with seven criteria, namely initial deposit, subsequent deposits, administrative costs, depositional balances, interest rates, age range, and facilities. This system can help the prospective customers determine the ideal savings place for the future needs. This study shows that the highest final value after calculation is 0.0320 for Batara of BTN bank, and the lowest value is 0.0132 for Tapres of BCA bank.
\end{abstract}

Keyword: Bank, Decision Support System, Weighted Product (WP)

\section{Introduction}

Menabung merupakan kebutuhan yang cukup penting untuk mempersiapkan masa depan bagi setiap calon nasabah. Setiap calon nasabah pasti menginginkan simpanan atau tabungan yang berkualitas khususnya dari pihak bank. Semakin banyak jumlah bank yang ada, masing-masing menawarkan kriteria-kriteria dan keunggulan yang berbeda-beda. Kriteria-kriteria dan keunggulan tersebut merupakan sebagai bahan pertimbangan bagi calon nasabah dalam memilih bank untuk membuka tabungan. Semakin banyaknya pilihan bank, maka akan semakin membingungkan bagi calon nasabah untuk memilih bank mana yang tepat untuk menabung. Tanpa adanya data dan informasi kuantitatif sebagai penunjang proses pemilihan bank, maka pemilihan tidak menjadi objektif dan terkadang terjadi kekeliruan dalam memilih bank yang dampaknya akan mengakibatkan kerugian materiil dalam jangka waktu yang panjang untuk calon nasabah itu sendiri. Karena sebagian besar calon nasabah menginginkan keuntungan dalam menabung.

Bank merupakan suatu badan yang bertujuan untuk memuaskan kebutuhan kredit, baik dengan alatalat pembayarannya sendiri atau dengan uang yang diperolehnya dari orang lain, maupun dengan jalan mengedarkan alat-alat penukar baru berupa uang giral [1].

Beberapa penelitian yang terkait antara lain seperti penelitian mengenai pemilihan bank untuk pembukaan rekening bagi calon nasabah, dalam penelitian ini menggunakan metode TOPSIS. Hasil dari penelitian ini selanjutnya dapat digunakan untuk membantu dalam perhitungan pemilihan bank berdasarkan nilai standar dari narasumber dan kriteria dari sistem dan nilai hasil kuisioner dari responden, karena perhitungan dalam TOPSIS yang lebih detail. Pada penelitian ini dihasilkan aplikasi berbasis website untuk memudahkan pengguna dalam segi fleksibilitas yang dapat digunakan dimanapun pengguna berada, serta aplikasi ini menggunakan sistem yang mudah untuk diakses melalui browser [2].

Dalam penetitian mengenai pemilihan hotel di kota Palembang, digunakan metode Simple Additive Weighting (SAW)". Dengan adanya sistem pendukung keputusan pemilihan hotel di kota Palembang dapat membantu para calon pengunjung dalam melakukan proses keputusan pemilihan hotel dengan cepat dan tepat, serta mampu memberikan rekomendasi keputusan hotel terpilih secara lebih objektif [3].

Selanjutnya penelitiaan mengenai penggunaan Fuzzy Logic untuk seleksi mahasiswa penerima beasiswa, dalam penelitian ini sistem dirancang dengan menggunakan motode fuzzy database model tahani. Hasil akhir dari penelitian ini bahwa aplikasi yang dibangun dapat membantu menghasilkan keputusan yang lebih cepat untuk dijadikan bahan pertimbangan dalam penyeleksian mahasiswa penerima beasiswa. Sistem ini tidak akan dapat memberikan hasil yang benar apabila kriteria yang dimasukkan tidak lengkap, sehingga penilai dapat menentukan sendiri kriteria yang diinginkan [4]. Penelitian serupa juga pernah dilakukan dengan beberapa kriteria antara lain seperti : penghasilan wali murid, peringkat kelas, ketidak hadiran, catatan BP, dan uang saku sebagai variabel pendukungnya [5].

Selanjutnya penelitian mengenai seleksi calon karyawan, penyelesaian pada kasus ini menggunakan Weighted Product Model. Hasil penelitian ini dapat digunakan sebagai acuan acuan dalam pengambilan keputusan secara tepat [6]. 
Selanjutnya penelitian mengenai monitoring pegawai, dalam penelitian ini digunakan Metode Fuzzy Multiple Attribute Decision Making (FMADM) dan Weighted Product (WP). Dalam penelitian ini dirancang sebuah prototipe sistem pendukung keputusan untuk menentukan pegawai kelurahan terbaik dengan menggunakan metode fuzzy FMADM dan WP. Pada perhitungan penelitian tersebut menghasilkan proses akhir perangkingan jumlah total nilai yang diurutkan dari yang tertinggi sampai terendah. Dengan kesimpulan bahwa sistem yang dirancang dengan mengimplementasikan metode Fuzzy Multiple Attribute Decision Making (FMADM) dengan Weighted Product (WP) dapat digunakan untuk membantu pegawai dalam melakukan pengambilan keputusan penilaian pegawai terbaik [7].

Dalam penelitian ini dirumuskan beberapa masalah yaitu: (1) Bagaimana merancang sebuah prototipe sistem untuk sistem pendukung keputusan rekomendasi pemilihan bank untuk pembukaan rekening menggunakan metode Weighted Product (WP)? (2) Bagaimana unjuk kerja sistem pendukung keputusan rekomendasi pemilihan bank untuk pembukaan rekening menggunakan metode Weighted Product (WP)?

Selanjutnya tujuan dari penelitian ini antara lain: (1) Membuat suatu prototipe sistem pendukung keputusan pemilihan bank untuk pembukaan rekening menggunakan metode Weighted Product (WP) yang dapat membantu masyarakat dalam pemilihan bank untuk pembukaan rekening secara efektif. (2) Mengetahui unjuk kerja sistem pendukung keputusan pemilihan bank untuk pembukaan rekening menggunakan metode Weighted Product (WP).

Diharapkan penelitian ini dapat dimanfaatkan untuk: (1) Sebagai sarana untuk membantu dalam menentukan bank mana yang lebih efektif untuk pembukaan rekening. (2) Masyarakat tidak harus mendatangi bank satu per satu untuk mengetahui fasilitas yang lebih menguntungkan untuk menabung.

Sistem pendukung keputusan (SPK) biasanya dibangun untuk mendukung solusi atas suatu masalah atau untuk mengevaluasi suatu peluang atau sering juga disebut sebagai aplikasi SPK. Aplikasi SPK biasanya menggunakan CBIS (Computer Based Information System) yang fleksibel, interaktif, dan dapat diadaptasi, yang dikembangkan untuk mendukung solusi atas masalah manajemen spesifik yang tidak terstruktur [8].

Dalam penelitian ini menggunakan metode Weighted Product(WP) dengan langkah penyelesaian [9] :

1. Menggunakan perkalian untuk menghubungkan atribut.

2. Rating setiap atribut harus dipangkatkan dulu dengan bobot atribut yang bersangkutan.

3. Dilakukan perbaikan bobot (W), sehingga menghasilkan bobot baru (W baru), seperti pada Persamaan 1.

$$
\boldsymbol{W}_{\boldsymbol{j}}=\frac{\boldsymbol{w}_{\boldsymbol{j}}}{\sum \boldsymbol{w}_{\boldsymbol{j}}} \text { jumlah } \mathrm{W}_{\mathrm{j}}=1
$$

Persamaan 1

4. Mencari vektor $\mathrm{S}$ dan dilanjut mencari vektor $\mathrm{V}$ yang digunakan untuk perangkingan. Metode WP menggunakan perkalian untuk menghubungkan rating atribut, dimana rating setiap atribut harus dipangkatkan dulu dengan bobot atribut yang bersangkutan. Proses ini sama halnya dengan proses normalisasi. Preferensi untuk alternatif $A_{i}$ diberikan seperti pada Persamaan 2.

$$
S_{i}=\prod_{j=1}^{n} X_{i j}^{w_{i j}}
$$

Dimana $\sum=$ wj adalah pangkat bernilai positif untuk atribut keuntungan, dan bernilai negatif untuk atribut biaya. Sedangkan preferensi relatif dari setiap alternatif, seperti pada Persamaan 3.

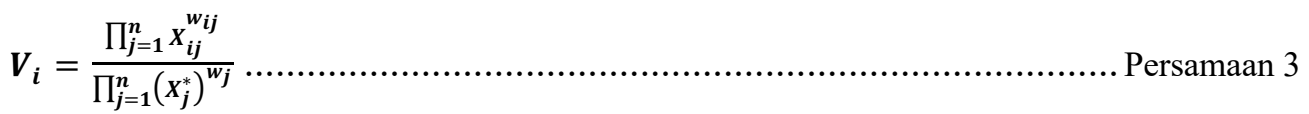

5. Hasil akhir perolehan dari proses perangkingan yaitu menghasilkan nilai terbesar sehingga diperoleh nilai terbesar yang dipilih sebagai altematif terbaik $\left(\mathrm{A}_{\mathrm{i}}\right)$ sebagai solusi.

\section{Research Method}

Secara garis besar proses jalannya penelitian ini dibagi menjadi empat tahapan, yaitu : (1) Inteligensi, (2) Desain, (3) Pemilihan, dan (4) Implementasi dan solusi [10]. Selanjutnya jalannya penelitian dapat dilihat pada Gambar 1. 


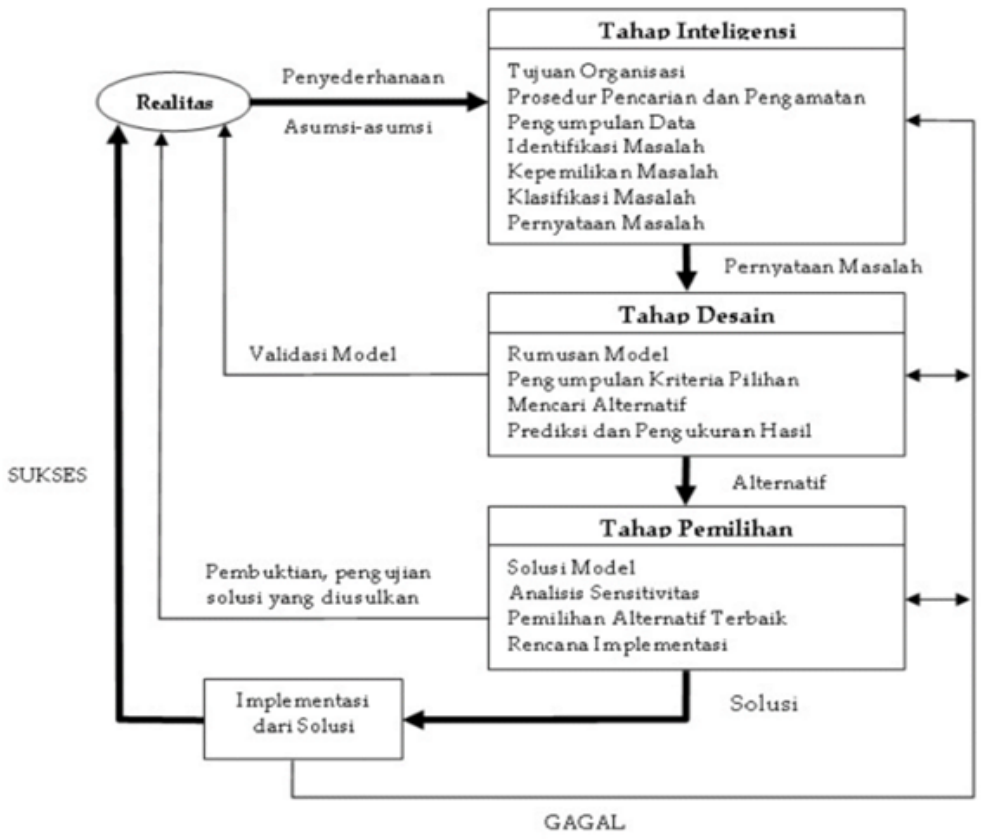

Gambar 1. Desain Sistem [10]

\subsection{Intelegensi}

Dalam penelitian teknik pengumpulan data merupakan faktor terpenting demi keberhasilan penelitian, yaitu : (a) Observasi, (b) Studi Kepustakaan.

\subsection{Desain}

Dalam penyelesaian langkah yang harus dilakukan :

1. Menentukan Kriteria

Kriteria untuk pengambilan keputusan daoat dilihat pada Tabel 1.

2. Menentukan rating kecocokan setiap alternatif pada setiap kriteria.

Rating kecocokan setiap alternatif pada setiap kriteria dinilai dengan 1 sampai 5 seperti pada Tabel 2.

Tabel 1. Kriteria

\begin{tabular}{cl}
\hline Kode & \multicolumn{1}{c}{ Jenis Kriteria } \\
\hline K1 & Setoran Awal \\
K2 & Setoran Selanjutnya \\
K3 & Biaya Administrasi \\
K4 & Saldo Pengendapan \\
K5 & Suku Bunga \\
K6 & Jangka Usia \\
K7 & Fasilitas
\end{tabular}

Tabel 2. Tabel Keterangan Bobot Kriteria

\begin{tabular}{ccc}
\hline Bobot & Keterangan & Nilai \\
\hline SK & Sangat Kurang & 1 \\
K & Kurang & 2 \\
C & Cukup & 3 \\
B & Baik & 4 \\
SB & Sangat Baik & 5 \\
\hline
\end{tabular}

\subsection{Pemilihan}

Dalam tahap pemilihan ini akan dilakukan langkah dari penyelesaian dengan metode Weighted Product (WP), yaitu membuat matriks keputusan berdasarkan kriteria, kemudian melakukan normalisasi matriks berdasarkan Persamaan yang disesuaikan dengan jenis atribut sehingga diperoleh matriks ternormalisasi R. Rating kecocokan setiap alternatif pada kriteria diberikan seperti Tabel 3.

Tabel 3. Tabel Rating Kecocokan

\begin{tabular}{|l|c|c|c|c|c|c|c|}
\hline Alternatif & K1 & K2 & K3 & K4 & K5 & K6 & K7 \\
\hline A1 & SB & SB & SB & SB & C & SB & K \\
\hline A2 & SB & SB & SB & SB & K & SB & C \\
\hline A3 & SB & SK & C & SB & SB & SB & C \\
\hline
\end{tabular}




\begin{tabular}{|c|c|c|c|c|c|c|c|}
\hline Alternatif & K1 & K2 & K3 & K4 & K5 & K6 & K7 \\
\hline A4 & SB & SB & SB & SB & SK & SB & $\mathrm{K}$ \\
\hline A5 & SB & SB & SB & SB & SK & SB & $\mathrm{K}$ \\
\hline A6 & SB & SB & SB & SB & SK & SB & SB \\
\hline A7 & SB & SB & B & SB & $\mathrm{K}$ & SB & SB \\
\hline A8 & SB & C & C & SB & B & SB & SB \\
\hline A9 & SB & C & C & SB & SK & SB & SB \\
\hline A10 & SB & SB & B & SB & SK & SB & SB \\
\hline A11 & SB & SK & K & SB & SK & SB & SB \\
\hline A12 & SB & SB & B & SB & $\mathrm{K}$ & SB & $\mathrm{K}$ \\
\hline A13 & SB & SB & C & SB & $\mathrm{K}$ & SB & $\mathrm{K}$ \\
\hline A14 & SK & SB & $\mathrm{C}$ & SK & SK & SB & C \\
\hline A15 & SB & SB & SB & SB & SK & SB & $\mathrm{C}$ \\
\hline A16 & SB & SB & $\mathrm{C}$ & SB & SK & SB & C \\
\hline A17 & SK & SB & B & SB & K & SB & $\mathrm{K}$ \\
\hline A18 & $\mathrm{C}$ & SB & SB & SB & SK & SB & $\mathrm{K}$ \\
\hline A19 & SB & SB & $\mathrm{K}$ & SB & SK & SB & $\mathrm{K}$ \\
\hline A 20 & SB & SB & SB & SB & $\mathrm{K}$ & SB & $\mathrm{C}$ \\
\hline A21 & SB & SB & C & SB & K & SB & B \\
\hline A 22 & B & SB & K & B & $\mathrm{K}$ & SB & B \\
\hline A23 & SB & SB & SB & SB & SK & SB & $\mathrm{C}$ \\
\hline A 24 & SB & SB & SB & SB & B & SB & SB \\
\hline A25 & SB & SB & $\mathrm{C}$ & SB & SK & SB & B \\
\hline A26 & SB & SB & B & SB & SK & SB & $\mathrm{C}$ \\
\hline A27 & SB & SB & $\mathrm{B}$ & SB & C & SB & $\mathrm{K}$ \\
\hline A28 & SB & SB & SB & SB & C & SB & $\mathrm{K}$ \\
\hline A29 & SB & SB & SB & SB & SK & SB & $\mathrm{K}$ \\
\hline A30 & SB & SB & SK & $\mathrm{SB}$ & SK & SB & $\mathrm{K}$ \\
\hline A31 & SB & SB & B & SB & $\mathrm{K}$ & SB & C \\
\hline A32 & SB & SB & B & SB & $\mathrm{K}$ & SB & C \\
\hline A33 & SB & SB & SB & SB & $\mathrm{K}$ & SB & $\mathrm{S}$ \\
\hline A34 & SB & SB & B & SB & SK & SB & $\mathrm{K}$ \\
\hline A35 & SB & SB & SB & SB & SK & SB & C \\
\hline A36 & SB & SB & SB & SB & SK & SB & $\mathrm{C}$ \\
\hline A37 & SB & SB & SB & SB & SK & SB & $\mathrm{C}$ \\
\hline A38 & SB & SB & $\mathrm{C}$ & SB & SK & SB & C \\
\hline A39 & SB & SB & SB & SB & SK & SB & $\mathrm{C}$ \\
\hline A40 & SB & SB & SB & SB & SK & SB & $\mathrm{C}$ \\
\hline A41 & SB & SB & SB & SB & K & SB & $\mathrm{C}$ \\
\hline A42 & SB & SB & B & SB & SK & SB & C \\
\hline A43 & SB & SB & C & SB & K & SB & C \\
\hline
\end{tabular}

\subsection{Implementasi dan Solusi}

\subsubsection{Perancangan DFD}

Data Flow Diagram (DFD) Level 0 dapat dilihat seperti pada Gambar 2. 


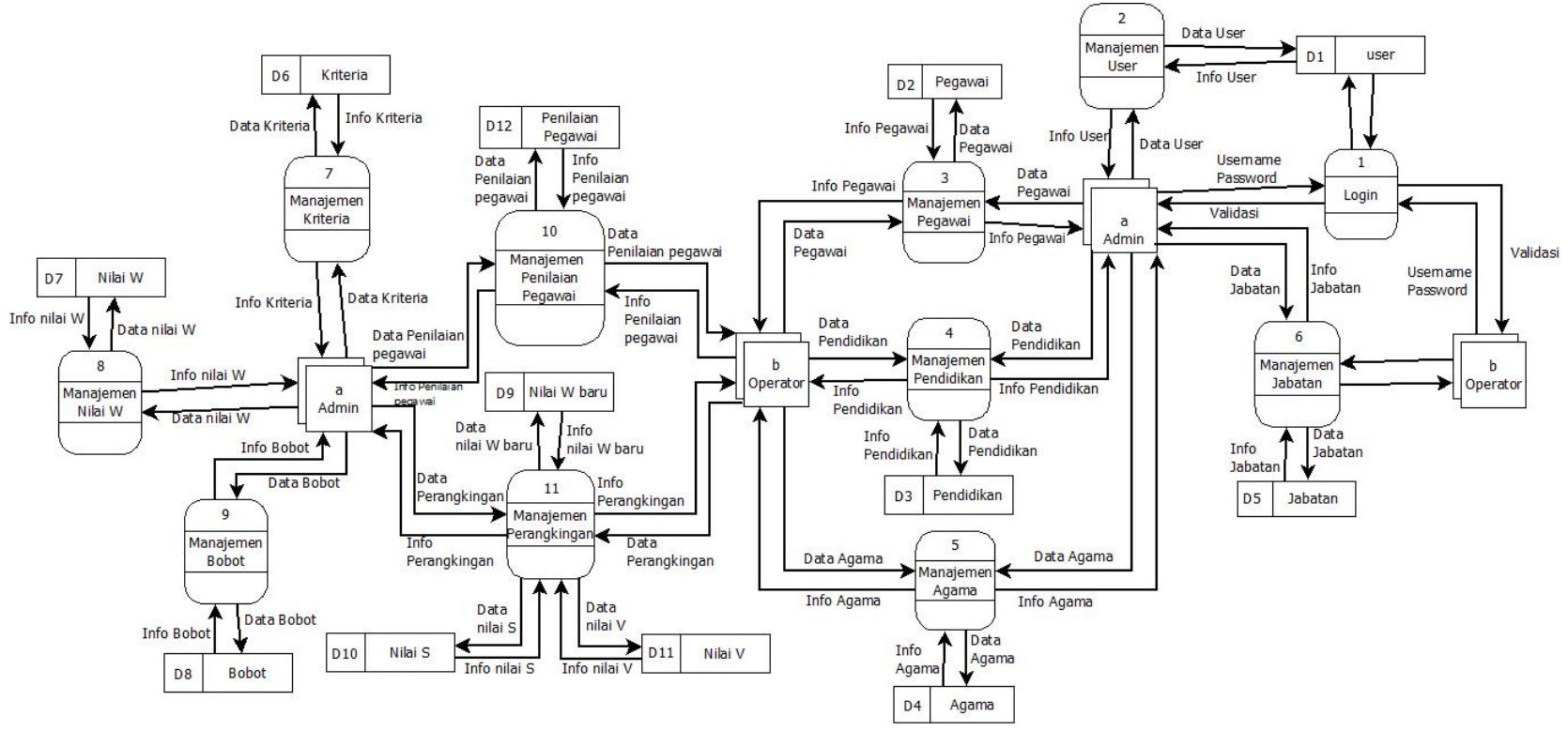

Gambar 2. DFD Level 0

\subsubsection{Flowchart Sistem}

Flowchart sistem dapat dilihat pada Gambar 3.

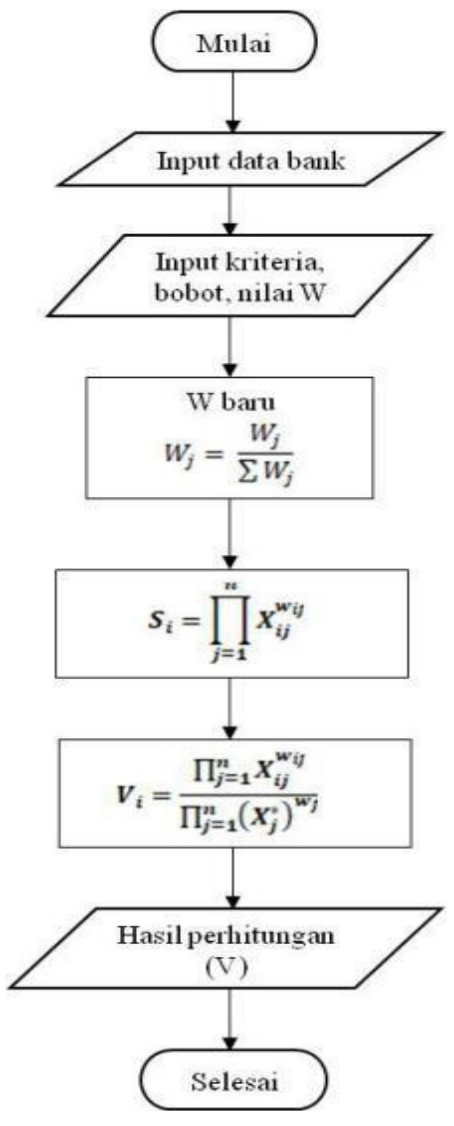

Gambar 3. Flowchart Sistem

\subsubsection{Perancangan Database}

Relasi tabel dalam penelitian ini, dapat dilihat pada Gambar 4. 


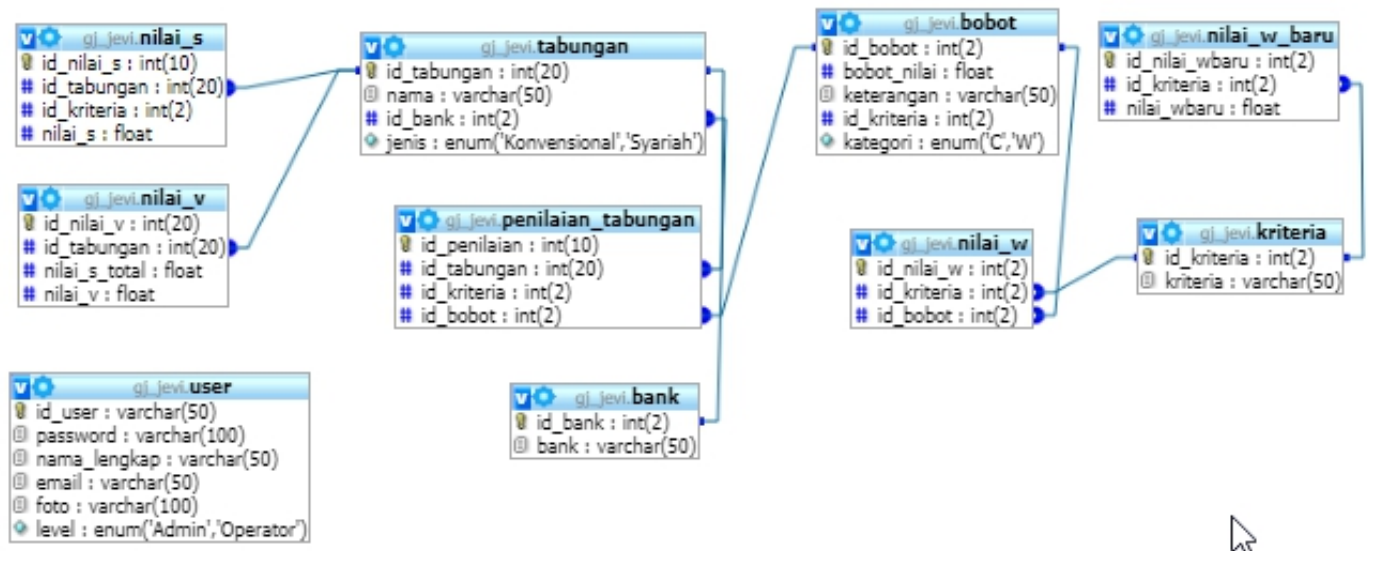

Gambar 4. Relasi Tabel

\section{Result and Analysis} Tabel 4 .

Matriks keputusan X yang telah dikonversikan berdasarkan bobot pada Tabel 2, dapat dilihat pada

Tabel 4. Tabel Matriks Keputusan X

\begin{tabular}{|l|c|c|c|c|c|c|c|}
\hline \multicolumn{1}{|c|}{ Alternatif } & K1 & K2 & K3 & K4 & K5 & K6 & K7 \\
\hline A1 & 5 & 5 & 5 & 5 & 3 & 5 & 2 \\
\hline A2 & 5 & 5 & 5 & 5 & 2 & 5 & 3 \\
\hline A3 & 5 & 1 & 3 & 5 & 5 & 5 & 3 \\
\hline A4 & 5 & 5 & 5 & 5 & 1 & 5 & 2 \\
\hline A5 & 5 & 5 & 5 & 5 & 1 & 5 & 2 \\
\hline A6 & 5 & 5 & 5 & 5 & 1 & 5 & 5 \\
\hline A7 & 5 & 5 & 4 & 5 & 2 & 5 & 5 \\
\hline A8 & 5 & 3 & 3 & 5 & 4 & 5 & 5 \\
\hline A9 & 5 & 3 & 3 & 5 & 1 & 5 & 5 \\
\hline A10 & 5 & 5 & 4 & 5 & 1 & 5 & 5 \\
\hline A11 & 5 & 1 & 2 & 5 & 1 & 5 & 5 \\
\hline A12 & 5 & 5 & 4 & 5 & 2 & 5 & 2 \\
\hline A13 & 5 & 5 & 3 & 5 & 2 & 5 & 2 \\
\hline A14 & 1 & 5 & 3 & 1 & 1 & 5 & 3 \\
\hline A15 & 5 & 5 & 5 & 5 & 1 & 5 & 3 \\
\hline A16 & 5 & 5 & 3 & 5 & 1 & 5 & 3 \\
\hline A17 & 1 & 5 & 4 & 5 & 2 & 5 & 2 \\
\hline A18 & 3 & 5 & 5 & 5 & 1 & 5 & 2 \\
\hline A19 & 5 & 5 & 2 & 5 & 1 & 5 & 2 \\
\hline A20 & 5 & 5 & 5 & 5 & 2 & 5 & 3 \\
\hline A21 & 5 & 5 & 3 & 5 & 2 & 5 & 4 \\
\hline A22 & 4 & 5 & 2 & 4 & 2 & 5 & 4 \\
\hline A23 & 5 & 5 & 5 & 5 & 1 & 5 & 3 \\
\hline A24 & 5 & 5 & 5 & 5 & 4 & 5 & 5 \\
\hline A25 & 5 & 5 & 3 & 5 & 1 & 5 & 4 \\
\hline A26 & 5 & 5 & 4 & 5 & 1 & 5 & 3 \\
\hline A27 & 5 & 5 & 4 & 5 & 3 & 5 & 2 \\
\hline A28 & 5 & 5 & 5 & 5 & 3 & 5 & 2 \\
\hline A29 & 5 & 5 & 5 & 5 & 1 & 5 & 2 \\
\hline A30 3 & 5 & 1 & 5 & 1 & 5 & 2 \\
\hline A31 & 5 & 5 & 4 & 5 & 2 & 5 & 3 \\
\hline A32 & 5 & 5 & 4 & 5 & 2 & 5 & 3 \\
\hline A33 3 & 5 & 5 & 5 & 5 & 2 & 5 & 2 \\
\hline A34 & 5 & 5 & 4 & 5 & 1 & 5 & 2 \\
\hline A35 & 5 & 5 & 5 & 5 & 1 & 5 & 3 \\
\hline
\end{tabular}




\begin{tabular}{|l|c|c|c|c|c|c|c|}
\hline Alternatif & K1 & K2 & K3 & K4 & K5 & K6 & K7 \\
\hline A36 & 5 & 5 & 5 & 5 & 1 & 5 & 3 \\
\hline A37 & 5 & 5 & 5 & 5 & 1 & 5 & 3 \\
\hline A38 & 5 & 5 & 3 & 5 & 1 & 5 & 3 \\
\hline A39 & 5 & 5 & 5 & 5 & 1 & 5 & 3 \\
\hline A40 & 5 & 5 & 5 & 5 & 1 & 5 & 3 \\
\hline A41 & 5 & 5 & 5 & 5 & 2 & 5 & 3 \\
\hline A42 & 5 & 5 & 4 & 5 & 1 & 5 & 3 \\
\hline A43 & 5 & 5 & 3 & 5 & 2 & 5 & 3 \\
\hline
\end{tabular}

Pengambil keputusan memberukan bobot berdasarkan tingkat kepentingan masing-masing kriteria yang dibutuhkan sebagai berikut:

Vektor bobot: $\mathrm{W}=[5,4,5,3,5,2,3]$

Sebagai contoh untuk melakukan perhitungan dengan metode WP, diambil 3 data sampel yaitu A1, A2, dan A3. Sehingga matriks keputusan X, dapat dilihat seperti berikut.

$$
X=\left[\begin{array}{lllllll}
5 & 5 & 5 & 5 & 3 & 5 & 2 \\
5 & 5 & 5 & 5 & 2 & 5 & 3 \\
5 & 1 & 3 & 5 & 5 & 5 & 3
\end{array}\right]
$$

Untuk mencari nilai W baru menggunakan Persamaan 1 sehingga :

$$
\begin{aligned}
& \mathrm{W}=[5,4,5,3,5,2,3] \\
& \mathrm{W}_{1}=\frac{5}{5+4+5+3+5+2+3}=0.1852 \\
& \mathrm{~W}_{2}=\frac{4}{5+4+5+3+5+2+3}=0.1481 \\
& \mathrm{~W}_{3}=\frac{5}{5+4+5+3+5+2+3}=0.1852 \\
& \mathrm{~W}_{4}=\frac{3}{5+4+5+3+5+2+3}=0.1111 \\
& \mathrm{~W}_{5}=\frac{5}{5+4+5+3+5+2+3}=0.1852 \\
& \mathrm{~W}_{6}=\frac{2}{5+4+5+3+5+2+3}=0.0741 \\
& \mathrm{~W}_{7}=\frac{3}{5+4+5+3+5+2+3}=0.1111
\end{aligned}
$$

Kemudian vektor S dihitung berdasarkan Persamaan 2.

$S_{1}=\left(5^{-0.1852}\right)\left(5^{-0.1481}\right)\left(5^{-0.1852}\right)\left(5^{-0.1111}\right)\left(3^{-0.1852}\right)\left(5^{-0.0741}\right)\left(2^{-0.1111}\right)=0.3480$

$S_{2}=\left(5^{-0.1852}\right)\left(5^{-0.1481}\right)\left(5^{-0.1852}\right)\left(5^{-0.1111}\right)\left(2^{-0.1852}\right)\left(5^{-0.0741}\right)\left(3^{-0.1111}\right)=0.2508$

$S_{3}=\left(5^{-0.1852}\right)\left(1^{-0.1481}\right)\left(3^{-0.1852}\right)\left(5^{-0.1111}\right)\left(5^{-0.1852}\right)\left(5^{-0.0741}\right)\left(3^{-0.1111}\right)=0.2953$

Selanjutnya hitung vektor V berdasarkan Persamaan 3.

$$
\begin{aligned}
& V_{1}=\frac{0.3480}{0.3480+0.2508+0.2953}=\frac{0.3480}{0.8941}=0.3892 \\
& V_{2}=\frac{0.2508}{0.3480+0.2508+0.2953}=\frac{0.2508}{0.8941}=0.2805 \\
& V_{3}=\frac{0.2953}{0.3480+0.2508+0.2953}=\frac{0.2953}{0.8941}=0.3303
\end{aligned}
$$

Kesimpulan hasil perangkingan seluruh data bisa dilihat pada Gambar 5. 


\begin{tabular}{|c|c|c|c|}
\hline No. & Kode Tabungan & Nama Tabungan & Nilai Akhir (v) \\
\hline 1 & 24 & Batarapos & 0.0320 \\
\hline 2 & 1 & Tandamata & 0.0274 \\
\hline 3 & 28 & Tab. Pasti & 0.0274 \\
\hline 4 & 7 & Tabungan mandiri & 0.0270 \\
\hline 5 & 8 & Berbagi & 0.0270 \\
\hline 6 & 2 & T.Gold & 0.0266 \\
\hline 7 & 41 & Tabungan BISA iB & 0.0266 \\
\hline 8 & 20 & Taplus muda & 0.0266 \\
\hline 9 & 27 & Taseto Premium & 0.0263 \\
\hline 10 & 32 & Simpeda & 0.0255 \\
\hline 11 & 31 & Bima & 0.0255 \\
\hline 12 & 33 & Tabunganku & 0.0254 \\
\hline 13 & 21 & Taplus & 0.0250 \\
\hline 14 & 6 & Danamon lebih & 0.0248 \\
\hline 15 & 12 & Simpedes & 0.0244 \\
\hline 16 & 43 & Utama iB & 0.0242 \\
\hline 17 & 10 & Dana & 0.0238 \\
\hline 18 & 37 & Syariah Mandiri & 0.0234 \\
\hline 19 & 39 & Tabungan Haji & 0.0234 \\
\hline 20 & 23 & Juara & 0.0234 \\
\hline 21 & 35 & Wadiah & 0.0234 \\
\hline 22 & 40 & Tahapan IB & 0.0234 \\
\hline 23 & 15 & Tahapan Xpresi & 0.0234 \\
\hline 24 & 36 & Mudhorobah & 0.0234 \\
\hline 25 & 13 & Britama & 0.0232 \\
\hline 26 & 3 & Super combo & 0.0226 \\
\hline 27 & 26 & Panin tab & 0.0225 \\
\hline 28 & 42 & Tab. Pas & 0.0225 \\
\hline 29 & 29 & Tabunganku & 0.0224 \\
\hline 30 & 5 & Mu & 0.0224 \\
\hline 31 & 4 & Si Pinter & 0.0224 \\
\hline 32 & 25 & CIMB Niaga Xtra & 0.0220 \\
\hline 33 & 22 & Prima & 0.0217 \\
\hline 34 & 34 & Siaga & 0.0215 \\
\hline 35 & 16 & Tahapan & 0.0213 \\
\hline 36 & 38 & Haji dan Umrah & 0.0213 \\
\hline 37 & 9 & Maxi & 0.0209 \\
\hline 38 & 18 & woman one & 0.0204 \\
\hline 39 & 19 & Regular (Tabungan) & 0.0189 \\
\hline 40 & 17 & Gold (Maksi) & 0.0181 \\
\hline 41 & 30 & U.Save & 0.0166 \\
\hline 42 & 11 & Ultima & 0.0165 \\
\hline 43 & 14 & Tapres & 0.0132 \\
\hline
\end{tabular}

Gambar 5. Hasil Perangkingan

\section{Conclusion}

Berdasarkan hasil penelitian maka dapat disimpulkan:

1. Prototipe sistem dirancang dengan mengimplementasikan metode Weighted Product (WP) dapat digunakan untuk membantu nasabah dalam mengambil keputusan manakah bank yang paling tepat untuk menabung.

2. Perhitungan menghasilkan nilai akhir tertinggi untuk tabungan yaitu 0.0320 pada bank BTN Batara dan nilai terendah 0.0132 pada bank BCA Tapres.

Saran untuk penelitian selanjutnya penelitian selanjutnya antara lain :

1. Dalam pembuatan bobot masih asumtif, agar lebih optimal maka dapat digunakan kuesioner terkait dengan kriteria untuk mendapatkan bobot nilai W. 
2. Penambahan variabel yang dapat dilakukan dengan survei ataupun wawancara lanjutan.

\section{References}

[1] T. Suyatno, D. T. Marala, A. Abdullah, J. T. Aponno, T. Y. Ananda dan H. A. Chalik, Kelembagaan Perbankan, Jakarta: PT. Gramedia Pustaka Utama, 2007.

[2] H. Nugraha, S. Maharani dan D. M. Khairina, "Sistem Pendukung Keputusan Rekomendasi Pemilihan Bank," dalam Prosiding Seminar Tugas Akhir FMIPA UNMUL 2015, Periode Juni 2015, ISBN : 978602-72658-0-6, Samarinda, 2015.

[3] D. C. Hartini, A. Ibrahim dan E. L. Ruskan, "Sistem Pendukung Keputusan Pemilihan Hotel Di Kota Palembang Dengan Metode Simple Additive Weighting (SAW)," Sistem Informasi, VOL.5, pp. 546-565, 2015.

[4] Arman dan Defiariany , "Sistem Pendukung Keputusan Dengan Metode Fuzzy Logic," Jurnal Edik Informatika, Vol 2, No 1 (2015), ISSN : 2407-0491, E-ISSN : 2541-3716, pp. 45-52, 2015.

[5] A. Sanjaya dan R. Ningsih, "Sistem Pendukung Keputusan Penentuan Calon Penerima Beasiswa Menggunakan Metode Fuzzy Database Model Tahani," Jurnal SIMETRIS, Vol 7 No 2 November 2016, ISSN: 2252-4983, pp. 449-458, 2016.

[6] S. Lestari, "Penerapan Metode Weighted Product Model Untuk Seleksi Calon Karyawan," Jurnal Sistem Informasi (JSI), VOL. 5, NO. 1, April 2013, ISSN Print : 2085-1588, ISSN Online : 2355-4614, pp. 540$545,2013$.

[7] M. R. N. Septian dan A. S. Purnomo, "Sistem Penilaian Pegawai Menggunakan Metode Fuzzy Multiple Attribute Decision Making (FMADM) dan Weighted Product (WP)," JMAI (Jurnal Multimedia \& Artificial Intelligence), Vol. 1, No. 1, Maret 2017, ISSN : 2580-2593, pp. 27-33, 2017.

[8] Kusrini, Konsep dan Aplikasi Sistem Pendukung Keputusan, Yogyakarta: Andi, 2007.

[9] S. Kusumadewi, S. Hartati, A. Harjoko dan R. Wardoyo, Fuzzy Multi- Atribute Decision Making (Fuzzy MADM), Yogyakarta: Graha Ilmu, 2006.

[10] E. Turban, J. E. Aronson dan T. P. Liang, Decision Support Systems and Intelligent Sistems (Sistem Pendukung Keputusan dan Sistem Cerdas), Yogyakarta: Andi, 2005. 